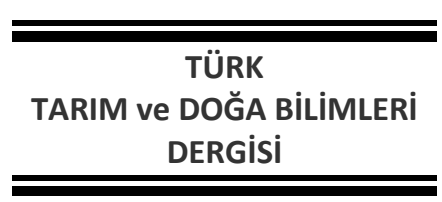

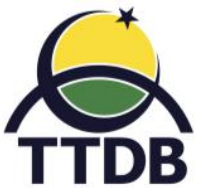

www.dergipark.gov.tr/turkjans

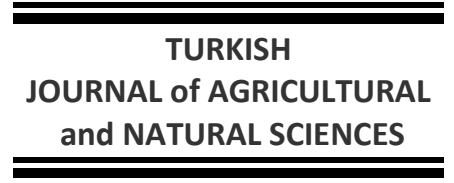

Araştırma Makalesi

\title{
Yerel Mercimek Genotiplerinin Verime Etki Eden Bazı Karakterleri İçin Genotipik ve Çevresel Etkilerin Belirlenmesi
}

\author{
Ufuk KARADAVUT*, Ömer SÖZEN
}

Ahi Evran Üniversitesi, Ziraat Fakültesi, Kırşehir

Sorumlu yazar: ufukkaradavut@gmail.com

Geliş Tarihi: 29.08.2019

Düzeltme Geliş Tarihi: 17.09.2019

Kabul Tarihi: 18.09.2019

Özet

Yerel mercimek (Lens culinaris Medik) genotiplerinin ıslahı için gerekli olan öncelikli özelliklerin belirlenmesi ve özelliklere ait kalıtım dereceleri ile genetik ilerleme değerlerinin ortaya konulması amacıyla yürütülen bu çalışma Ahi Evran Üniversitesinin Tarımsal Araştırma ve Uygulama arazisinde üç yıl süre ile sürdürülmüştür. Kırşehir ilinden toplanan ve tanımlaması gerçekleştirilen 31 adet yerel mercimek genotipi bu çalışmanın materyalini oluşturmuştur. Tesadüf Blokları Deneme Desenine göre üç tekrarlamalı olarak kurulan çalışmada incelenen değişkenlere ait tanımlayıc istatistikler ile değişkenlere ait varyanslar ve kalıtım dereceleri ortaya konulmuştur. Çalışma sonucunda bitkide bakla sayısı ile bitkide tane sayısı karakterlerinin kalıtım derecesi değerleri bakımından önde geldiği görülmüş olup bu karakterlerin aynı zamanda fenotipik, genotipik ve genotip x yıl etkileşim varyanslarına ait değişim katkılarının da yüksek olduğu ortaya konulmuştur. Buna göre yerel mercimek genotiplerinin ıslah programlarında daha başarılı bir şekilde değerlendirilebilmeleri için bu karakterler üzerinde özellikle durulması yararlı olacaktır.

Anahtar kelimeler: Mercimek, genotip, karakter, varyans, kalıtım derecesi.

\section{Determination of Genotypic and Environmental Effects of Some Lentil Genotypes Affecting Yield}

\begin{abstract}
This study was carried out for three years in Ahi Evran University Agricultural Research and Application area in order to determine the priority characteristics required for the breeding of local lentil (Lens culinaris Medik) genotypes and to determine the inheritance and genetic progress values of the traits. Material of this study consisted of 31 local lentil genotypes collected from Kırşehir province and identified. Descriptive statistics of the studied variables and variance and heritability of the variables were revealed in the study which was established in a randomized block design with three replications. As a result of the study, it was found that the number of pods per plant and number of grains per plant were leading in terms of heritability values and it was found that the contribution of change of phenotypic, genotypic and genotype $x$ year interaction variants was high. Accordingly, local lentil genotypes can be evaluated more successfully in breeding programs, it will be useful to emphasize these characters in particular.
\end{abstract}

Key words: Lentil, genotype, character, variance, degree of heredity.

Giriş

Ülkemizde yetiştirilen yemeklik tane baklagiller içinde mercimek (Lens culinaris Medik) bitkisinin anavatanının Türkiye olması ve yüzlerce yıldır sofralarımızdan eksik edilmemiş olması kullanımının artmasına sebep olmuştur. Vejetasyonu süresince kurak şartlara oldukça dayanıklı olması ve Orta Anadolu koşullarında marjinal alanlarda yetiştirilebilmesi bir avantaj olarak görülebilmektedir. Toprak seçiciliği 
olmadığından her türlü toprak koşullarında başarılı bir şekilde yetiştirilebilmekle beraber hafif alkali ve nötr topraklar istediği toprak tipi olarak kabul edilir (Sepetoglu, 1992; Bozoglu ve Peksen, 1997). Bir baklagil bitkisi olması nedeniyle ekim nöbeti sistemlerinde başarılı bir şekilde yer almaktadır. Düşük verimli toprakların ıslahında kullanılabilmektedir. Subhani ve ark. (2007) mercimeğin düşük verimli topraklarda başarılı bir şekilde yetiştirilebildiğini belirtirken, Shah ve ark. (2013) sadece kurak değil aynı zamanda sulanabilen ve yağış rejimi altında da başarılı olduğunu belirtmişlerdir. Sözen ve Karadavut (2017) Hatay koşullarında yürüttükleri bir çalışmada $1.300 \mathrm{~mm}$ yağış altında mercimek bitkilerinin oldukça iyi performans gösterdiklerini ve bölge için ekim nöbeti sistemine alınabileceğini belirtmişlerdir. Günümüzde mercimek tarımının en büyük sorunu geliştirilen genotiplerin belli bir verim kararlığına (stabiliteye) sahip olmamaları olarak belirtilmektedir (Karadavut ve Palta, 2010). Bunun sağlanabilmesi için yerel materyallerin daha etkin bir şekilde ön plana çıkarılması ve ıslah programlarına alınması gerekmektedir. Çünkü ekolojik koşullardaki farklılaşma genotiplerin tepkilerinde de ciddi değişmeler oluşmasına sebep olmaktadır (Kır ve Şahan, 2019). Bu değişimin en aza indirilebilmesi ancak yerel genotipler ile sağlanabilmektedir. Bununda mercimekte yerel genotiplerdeki genetik değişkenliğin çok yüksek olması ile sağlanabildiği belirtilmektedir (Rao ve Yadav, 1988). Mercimek üzerinde yapılan çalışmalarda tane iriliğinin arttırılması ve düşük sıcaklıklarda çiçeklenebilme ve bakla bağlama gücü iyi olan genotiplerin geliştirilmesi gerekmektedir (Singh ve Mehra, 1980). Kışlık olarak yapılan mercimek yetiştiriciliğinde bitki büyümesi ve gelişmesi aşamalarında ortaya çıkabilen yüksek ve düşük sıcaklıkların etkisi ile verim ve verime etki eden karakterlerde önemli sapmalar olabilmektedir. Sapmaların yönü verimliliğinde yönünü belirlediğinden genotiplerin performanslarında etkili olmaktadırlar (Sözen ve Karadavut, 2017). Özellikle farklı çevreler söz konusu olduğunda ortaya çıkan etkileşimler genetik olarak genotiplerin genotipik ve fenotipik özellikleri arasındaki ilişkinin azalmasına sebep olmaktadırlar (Baker ve ark., 1968). Bu da genetik çalışmalarda sonuç alınmasını zorlaştırmaktadır (Altınbaş ve Sepetoğlu, 2002). Bunun önlenebilmesi içinde genotiplerin farklı yer ve yıllarda denemelere alınarak varyans unsurları ile kalıtım derecelerini en iyi şekilde belirlemeye çalışılmalıdır (Özpınar ve ark., 2017).

Kırşehir ekolojik koşullarında yerel olarak yetiştirilen mercimek genotiplerin verim ve bazı tarımsal özellikleri üzerindeki genotip ve çevre etkileri ile kalıtım değerlerinin ortaya konulması bu çalışmanın amacını oluşturmaktadır.

\section{Materyal ve Yöntem}

Bu çalışma 2016-2018 yılları arasında 3 yıl süre ile Kırşehir ekolojik koşullarında yürütülmüştür. Çalışma Ahi Evran Üniversitesinin Araştırma ve Uygulama Deneme Arazilerinde kontrollü şartlarda gerçekleştirilmiştir. Materyal olarak Kırşehir genelinden toplanan ve tanımlanan saf hat haline getirilmiş ileri düzey 31 adet yerel mercimek genotipi kullanılmıştır. Deneme arazisinin iklim ve toprak özellikleri Çizelge 1 ve 2'de verilmiştir. Araştırmanın yürütüldüğü yetiştirme sezonları için; her üç yılda da ortalama sıcaklık en düşük Mart ayında $\left(7.1{ }^{\circ} \mathrm{C}, 7.3^{\circ} \mathrm{C}\right.$ ve $\left.5.3^{\circ} \mathrm{C}\right)$, en yüksek ise Temmuz ayında $\left(24.2{ }^{\circ} \mathrm{C}, 26.0{ }^{\circ} \mathrm{C}\right.$ ve $\left.23.0{ }^{\circ} \mathrm{C}\right)$ ölçülmüştür. Bu değerler uzun yıllar ortalaması olan değerlere çok yakındır. Yağış miktarı olarak ilk iki yıl Mayıs ayı ( $98.2 \mathrm{~mm}$ ve $49.9 \mathrm{~mm}$ ) en yüksek yağış alan ay olurken, üçüncü yıl Nisan ayı $(45.0 \mathrm{~mm})$ en yüksek yağış alan ay olmuş olup her üç yılda da yağış miktarları uzun yıllar yağış miktarları ile benzerlik göstermiştir. Nem miktarı olarak her üç yılda da çok ciddi değişimler olmamış ve \%36.0-67.9 aralığında nispi nem değerleri belirlenmiştir (Çizelge 1).

Çizelge 1. Denemenin yürütüldüğü Kırşehir iline ait iklim verileri

\begin{tabular}{|c|c|c|c|c|c|c|c|c|c|c|c|c|}
\hline \multirow[b]{2}{*}{ Aylar } & \multicolumn{4}{|c|}{ Ortalama sıcaklık $\left({ }^{0} \mathrm{C}\right)$} & \multicolumn{4}{|c|}{ Toplam yağış (mm) } & \multicolumn{4}{|c|}{ Ortalama nispi nem (\%) } \\
\hline & 2016 & 2017 & 2018 & $\begin{array}{l}\text { Uzun } \\
\text { yillar }\end{array}$ & 2016 & 2017 & 2018 & $\begin{array}{l}\text { Uzun } \\
\text { yıllar }\end{array}$ & 2016 & 2017 & 2018 & $\begin{array}{l}\text { Uzun } \\
\text { yillar }\end{array}$ \\
\hline Mart & 7.1 & 7.3 & 5.3 & 5.5 & 44.8 & 41.5 & 37.6 & 37.4 & 60.7 & 60.8 & 67.9 & 68.2 \\
\hline Nisan & 13.8 & 10.7 & 9.7 & 10.6 & 24.0 & 29.0 & 45.0 & 45.6 & 47.4 & 52.4 & 50.8 & 64.3 \\
\hline Mayıs & 14.9 & 15.2 & 13.6 & 15.3 & 98.2 & 49.9 & 40.8 & 43.9 & 63.7 & 59.4 & 61.4 & 61.4 \\
\hline Haziran & 21.0 & 20.7 & 19.5 & 19.4 & 18.5 & 18.4 & 36.2 & 36.9 & 53.0 & 54.3 & 56.1 & 55.1 \\
\hline Temmuz & 24.2 & 26.0 & 23.0 & 23.0 & 5.8 & 0.4 & 9.3 & 9.6 & 42.5 & 36.0 & 48.4 & 48.7 \\
\hline Ortalama & 16.2 & 16.0 & 14.2 & 14.8 & & & & & 53.5 & 52.6 & 56.9 & 59.5 \\
\hline Toplam & & & & & 191.3 & 139.2 & 173.0 & 244.0 & & & & \\
\hline
\end{tabular}

*Veriler Kırşehir İli Meteoroloji Müdürlüğünden alınmıştır. 
Araştırma arazisinin toprak yapısı; hafif alkali, organik maddesi az, alınabilir potasyum bakımından yeterli seviyededir. Alınabilir fosfor yüksek, tuzsuz ve kireçli olarak tespit edilmiştir (Çizelge 2).

3 yıl süre ile yürütülen çalışma tesadüf blokları deneme desenine göre üç tekrarlamalı olarak kurulmuştur. Parseller 5 metre uzunluğunda dört sıra, sıra arası mesafe $20 \mathrm{~cm}$ ve parsel büyüklüğü 5 × $0.8 \mathrm{~m}=4 \mathrm{~m}^{2}$ olarak ayarlanmıştır. Her üç yılda da ekim Mart ayının üçüncü haftasında (illk yıl 18 Mart, ikinci yıl 21 Mart ve üçüncü yıl ise 15 Mart tarihlerinde) yapılmıştır. Parsellere ekim ile birlikte $2 \mathrm{~kg}$ saf azot ve $5 \mathrm{~kg}$ fosfor olmak üzere DAP gübresi taban gübresi olarak verilmiştir. Her deneme yılında ekimden itibaren çıkışta bir kez yabancı ot mücadelesi el ile yapılmıştır. Her üç yılda da hasat işlemleri temmuz ayının ilk haftasında gerçekleştirilmiştir. Hasat işlemleri baklaların olgunlaşarak kurumaya başlamalarından itibaren el ile sökülmüşler ve daha sonra harman edilmişlerdir. Bitkilerde ölçüm işlemleri yapılırken, her parselden rastgele 10 'ar bitki seçilmiş ve ölçümler bu bitkiler üzerinden yapılmıştır. Araştırmada incelenen karakterler; bitki boyu, ilk bakla yüksekliği, ana dal sayısı, biyolojik verim, bitkide bakla sayısı, bitkide tane sayısı, bitki başına tane verimi, yüz tane ağırlığı ve hasat indeksi'dir. Elde edilen veriler SPSS 21 istatistik paket programında analiz edilmiştir. Genotip ve yıl etkileri ana etkiler olarak kabul edilmiş ve bunların etkileşimlerinin özelliklere olan oransal katkılarını belirlemek için sahip oldukları kareler ortalamaları beklenen değerlerine eşitlenerek tahmin edilen varyansların toplam değişimdeki payları (\%) olarak belirlenmiştir. Comstock ve Moll (1963) tarafından önerilen yöntem kullanılarak varyanslar tahmin edilmiş ve genotipik varyansın fenotipik varyansa oranlanmasıyla geniş anlamda kalıtım dereceleri hesaplanmıştır. Fenotipik ve genotipik varyansların oransal değerlerini ifade eden fenotipik ve genotipik değişkenlik katsayıları belirlenmiştir (Boerma ve Cooper, 1975; Tripathi, 1998). Populasyon içinde en iyi iki hat uygulanacak bir seçimden beklenen genetik ilerleme değerleri ölçüm birimi cinsinden ve genel ortalamanın yüzdesi olarak genetik ilerleme dereceleri belirlenmiştir (Allard, 1960).

Çizelge 2. Deneme yeri toprağının fiziksel ve kimyasal özellikleri.

\begin{tabular}{lcc}
\hline Derinlik & $\mathbf{0 - 3 0 ~} \mathbf{~ c m}$ & $\mathbf{3 0 - 6 0 ~} \mathbf{~ m}$ \\
\hline $\mathrm{pH}$ & 7.59 & 7.63 \\
Toplam tuz (\%) & 0.02 & 0.02 \\
Kireç $\left(\% \mathrm{CaCO}_{3}\right)$ & 27.90 & 28.39 \\
Doygunluk (\%) & 55.00 & 55.00 \\
Organik madde (\%) & 1.81 & 1.64 \\
Fosfor $\left(\mathrm{P}_{2} \mathrm{O}_{5} \mathrm{~kg} / \mathrm{da}\right)$ & 2.14 & 2.29 \\
Potasyum $\left(\mathrm{K}_{2} \mathrm{O}\right)$ & 66.62 & 51.47 \\
\hline
\end{tabular}

\section{Bulgular ve Tartışma}

İncelenen karakterlere ait sonuçlar Çizelge

3 'de gösterilmektedir. Çizelge incelendiğinde bitki boyu ortalamasının $23.78 \mathrm{~cm}$ olduğu görülmekle beraber oldukça büyük bir değişim genişliği değerine de $(15.00-49.80 \mathrm{~cm})$ sahip olduğu ortaya konulmuştur. Değişim genişliğinin artması standart sapmayı ve buna bağlı olarak varyansı artırmaktadır. Varyansın artması ise bitki boyu bakımından genotipler arasındaki farklıı̆ı̆ arttığını göstermektedir. En yüksek varyasyon yüz tane ağırlığında gözlenirken bunu hasat indeksi izlemiştir. Burada belirleyici olan değişim katsayılarına bakıldığında yüz tane ağırlığının oldukça yüksek bir değere sahip olduğu ve bunu bitkide tane veriminin izlediği görülmektedir. İlk bakla yüksekliği değişimin en az görüldüğü özellik olurken bunu ana dal sayısı izlemiştir. Bu sonuçlara göre ilk bakla yüksekliği bitki boyundaki değişimden ciddi oranda etkilenmemiştir. Ancak yüz tane ağırlığı ise oldukça yüksek oranda etkilenmiştir. Çevre faktörlerinin değişmesi aynı zamanda bitkinin yetişme sürelerini ve yetişme koşullarını de değiştirdiğinden tepkiler farklı olmakta ve adaptasyon sorunu yaşanabilmektedir. Schuler ve ark. (1995) ile Karadavut ve Palta (2010) çevredeki değişimin bitkilerde fiziksel ve kimyasal bazı değişimlere sebep olduğunu belirtmişlerdir. Sözen ve Karadavut (2017) ise özellikle yerel genotiplerin tepkilerinin çeşitlere göre daha yüksek oranlarda olduğunu bildirmişlerdir. Yürütülen çalışmada yerel materyalin kullanılması değişim katsayısının ve varyansın yüksek çıkmasında etkili olmuştur. Buda bize yerel mercimek genotipleri arasında önemli varyasyonların bulunduğunu göstermektedir.

Çalışmada kullanılan yerel mercimek genotiplerinde incelenen karakterlere ait varyans analiz sonuçları Çizelge 4'de verilmektedir. Çizelge 4 incelendiğinde yıl, ana dal sayısı özelliği hariç bütün özelliklerde önemli çıkmıştır. Yıl, önemlilik oranı bakımından bütün özelliklerde 0.01 'e göre çok önemli çıkarken, sadece biyolojik verimde 0.05 'e göre önemli çıkmıştır. Ana dal sayısında gözlenen bu kararlılık dal sayısının çevresel koşullardan çok fazla 
etkilenmediğini ortaya koymaktadır (Biçer, 2014). Kökten ve Bakoğlu (2011) baklagillerde ana dal sayında varyasyonun çok yüksek olmadığını belirtmişlerdir Yıl etkisi değişkenliğin önemli bir kaynağıdır. Yürütülen çalışmada da bir özellik dışında bütün özelliklerde önemli çıkması bunu açıkça göstermiştir. Pek çok araştırmacı yılın önemli olduğunu yaptıkları çalışmalarda vurgulamışlardır (Çokkızgın, 2007; Gharti ve ark., 2008; Karadavut ve Palta, 2010; Çölkesen ve ark., 2014; Akdeniz ve ark., 2019). Genotip bakımından bütün özelliklerin önemli olduğu görülmüştür. Yıl ve genotip etkileşimine bakıldığında ise genel olarak önemsizlik hakimdir (Çizelge 4).

Çizelge 3. Incelenen karakterlere ait tanımlayıcı istatistikler

\begin{tabular}{lccccccc} 
İncelenen karakterler & Ortalama & $\begin{array}{c}\text { Standart } \\
\text { hata }\end{array}$ & $\begin{array}{c}\text { Standart } \\
\text { sapma }\end{array}$ & Varyans & $\begin{array}{c}\text { Değişim } \\
\text { katsayısı }\end{array}$ & $\begin{array}{c}\text { En } \\
\text { küçük } \\
\text { değer }\end{array}$ & $\begin{array}{c}\text { En } \\
\text { büyük } \\
\text { değer }\end{array}$ \\
\hline Bitki boyu cm) & 23.78 & 0.34 & 5.67 & 32.23 & 23.87 & 15.00 & 49.80 \\
İlk bakla yüksekliği (cm) & 14.31 & 0.16 & 2.71 & 7.39 & 18.99 & 8.2 & 22.70 \\
Ana dal sayısı (adet) & 2.07 & 0.02 & 0.44 & 0.19 & 21.51 & 1.00 & 3.00 \\
Biyolojik verim (g) & 3.59 & 0.16 & 2.71 & 7.38 & 75.67 & 0.18 & 18.57 \\
Bitkide bakla sayısı (adet) & 21.74 & 0.89 & 14.90 & 222.23 & 68.55 & 1.00 & 89.00 \\
Bitkide tane sayısı (adet) & 16.12 & 0.70 & 11.72 & 137.42 & 72.68 & 1.00 & 72.00 \\
Bitki başına tane verimi (g) & 0.97 & 0.05 & 0.83 & 0.69 & 85.34 & 0.04 & 5.69 \\
Yüz tane ağırlığı (g) & 16.23 & 1.03 & 17.24 & 297.30 & 106.24 & 2.92 & 57.22 \\
Hasat indeksi (\%) & 31.54 & 0.94 & 15.78 & 249.24 & 50.05 & 1.14 & 60.87 \\
\hline
\end{tabular}

Çizelge 4. Değişkenlere ait kareler ortalaması değerleri

\begin{tabular}{lccc}
\hline \multirow{2}{*}{ Incelenen karakterler } & \multicolumn{2}{c}{ Değişim kaynakları } \\
\cline { 2 - 4 } & $10.638^{* *}$ & Genotip & Yıl X Genotip \\
\hline Bitki boyu & $5.106^{* *}$ & $1.632^{* *}$ & 1.085 \\
ilk bakla yüksekliği & 519 & $1.237^{*}$ & 967 \\
Ana dal sayısı & $2.301^{*}$ & $1.403^{*}$ & 1.012 \\
Biyolojik verim & $12.991^{* *}$ & $32.699^{* *}$ & $22.037^{*}$ \\
Bitkide bakla sayısı & $712^{* *}$ & $2.102^{* *}$ & 972 \\
Bitkide tane sayısı & $14.566^{* *}$ & $1.618^{*}$ & 1.008 \\
Bitki başına tane verimi & $6.894^{* *}$ & $1.521^{* *}$ & $1.263^{*}$ \\
Yüz tane ağırlığı & $5.847^{* *}$ & $1.139^{* *}$ & 1.201 \\
Hasat indeksi & & & $1.165^{*}$ \\
\hline
\end{tabular}

Kırşehir ekolojik koşulları altında yetiştirilen 31 adet yerel mercimek genotipinde incelenen karakterlere ait varyasyon kaynaklarının toplam değişkenlik içindeki etki payları Çizelge 5'de verilmiştir. Çizelge 5 incelendiğinde yıllara göre değişime en büyük katkı \%71.2 ile bitki boyunda gözlenirken bunu \%68.8 ile biyolojik verim ve \%56.4 ile bitki başına tane verimi izlemiştir. Bu üç özellik değişimin ana yönlendiricisi olarak etkide bulunmuşlardır. Yıllardaki değişim bu faktörleri diğerleri kadar etkilememiştir. Yıllara göre en az katkı payı ise \%18.4 ile ana dal sayısında olmuştur. Genotipler bakımından incelendiğinde değişime en büyük katkı \%29.1 ile yüz tane ağırlığında görülmüştür. Bu özelliği \%22.6 ile bitkide bakla sayısı izlemiştir. Bu iki özellik genotipik değişimin bakla ve tanelerde olduğunu göstermektedir. Bitkide tane sayısının da \%15.7 olması ve üçüncü en büyük katkıyı yapması tane verimi açısından dikkatli olunması gerektiğini vurgulamaktadır. Sözen ve ark. (2019) yerel genotiplerde varyasyonun yüksek olmasında tane veriminin etkili olduğunu ve değişim kaynaklarına etkisinin oldukça yüksek olduğunu belirtmişlerdir. Yıl x Genotip etkileşiminin katkısı incelendiğinde en yüksek katkının bitki başına tane veriminde $(\% 30,1)$ olduğu görülmüştür. Yıllara göre verimdeki değişimin çok yüksek olması değişime katkısını artırmıştır. Yıllara göre değişimin yerel genotiplerde en önemli sorun olduğu gibi düşünülse de ıslah materyallerinin önemli bir kaynağı olarak bu değişkenlik emsalsiz bir değer olarak kabul edilmektedir (Kan ve ark., 2019). Hatalara bakıldığında ise hataların 8.6 ile 15.3 arasında değişim gösterdiği görülmektedir. Genel olarak hataların sıfırdan uzaklaşma miktarlarının düşük olduğu görülmektedir. Çalışmalarda hatanın düşük olması çalışmanın güven derecesini artırmaktadır (Düzgüneş ve ark.1987).

Incelenen karakterlerde fenotipik, genotipik ve genotip x yıl etkileşimine ait varyanslar ile tahmin edilen kalıtım dereceleri Çizelge 6'da verilmektedir. Çizelge 6 incelendiğinde en yüksek fenotipik varyansın 21.8 ile bitkide bakla sayısında olduğu görülmektedir. Bunu 14.8 değeri ile bitkide tane 
sayısı izlemiştir. En düşük değer ise 2.2 ile ana dal sayısında tespit edilmiştir. Buna göre fenotipik varyansta belirleyici ve önde olan iki değişkenin üzerinde durulması faydalı olacaktır. Bu iki özellik aynı zamanda fenotip üzerinde yapılacak çalışmalara yol gösterici olabilecektir. Rao ve Yadav (1988) bitkide tane sayısının fentipik varyansta etkisinin yüksek olduğunu ve öncelik verilmesi gereken konular arasında olduğu belirtirken, Biçer ve Şakar (2008) fenotipik varyansın diğer varyansları etkileyici olması nedeniyle üzerinde durulması gerektiğini belirtmişlerdir. Genotipik varyans bakımından en yüksek varyans bitkide bakla sayısında tespit edilirken en düşük varyans ise biyolojik verimde görülmüştür. Fenotipik varyansın genel olarak fenotipik varyanstan daha düşük olduğu görülmektedir. $\mathrm{Bu}$ durum genotipik değişkenliğinin daha az olduğunu ve daha kararlı bir yapıya sahip olduğunu göstermektedir. Elde edilen bu sonuçlar Singh ve Bejiga (1990) ile Altınbaş ve Sepetoğlu (2002)'nun yaptıkları çalışmalar ile uyum içindedir. Özellikle biyolojik verimin çevreden etkilenme miktarı ile bitkide bakla sayısındaki değişkenlik bitkilerin aslında oldukça hassas bir denge üzerinde olduklarını göstermektedir.

Çizelge 5. Karakterlere ait varyasyon kaynaklarının toplam değişkenlik içindeki etki payları

\begin{tabular}{lcccc}
\hline İncelenen karakterler & Yıl & Genotip & Yıl x Genotip & Hata \\
\hline Bitki boyu & 71.3 & 4.8 & 6.3 & 10.2 \\
İlk bakla yüksekliği & 53.9 & 6.2 & 7.2 & 15.3 \\
Ana dal sayısı & 18.4 & 6.0 & 5.2 & 9.4 \\
Biyolojik verim & 68.8 & 3.2 & 10.4 & 12.0 \\
Bitkide bakla sayısı & 40.1 & 22.6 & 22.8 & 11.5 \\
Bitkide tane sayısı & 42.5 & 15.7 & 15.9 & 14.2 \\
Bitki başına tane verimi & 56.4 & 9.2 & 30.1 & 8.8 \\
Yüz tane ağırlığı & 44.1 & 29.1 & 13.5 & 10.1 \\
Hasat indeksi & 29.5 & 5.5 & 10.7 & 8.6 \\
\hline
\end{tabular}

Çizelge 6. Değişim kaynakları ve katılım dereceleri.

\begin{tabular}{lcccc}
\hline Incelene Karakterler & $\begin{array}{c}\text { Fenotipik } \\
\text { varyans }\end{array}$ & $\begin{array}{c}\text { Genotipik } \\
\text { varyans }\end{array}$ & $\begin{array}{c}\text { Genotip x Yıl } \\
\text { etkileşiminin varyansı }\end{array}$ & $\begin{array}{c}\text { Kalıtım } \\
\text { derecesi }\end{array}$ \\
\hline Bitki boyu & 12.3 & 5.1 & 2.3 & 91.0 \\
ilk bakla yüksekliği & 11.7 & 6.2 & 2.1 & 72.5 \\
Ana dal sayısı & 2.2 & 1.1 & 0.9 & 12.1 \\
Biyolojik verim & 8.4 & 0.8 & 18.3 & 81.3 \\
Bitkide bakla sayısı & 21.8 & 12.4 & 24.5 & 69.6 \\
Bitkide tane sayısı & 14.8 & 7.9 & 22.1 & 55.7 \\
Bitki başına tane verimi & 7.6 & 0.8 & 5.5 & 41.2 \\
Yüz tane ağırlığı & 6.4 & 5.4 & 3.8 & 68.5 \\
Hasat indeksi & 3.7 & 1.2 & 1.7 & 44.4 \\
\hline
\end{tabular}

Genotip x Yıl etkileşimi bakımından ise 24.5'lik varyans değeri ile bitkide bakla sayısında olduğu görülürken bunu 22.1 varyans değeri ile bitkide tane sayısı izlemiştir. Dikkat edilirse bitkide tane sayısı özelliği fenotipik varyans, genotipik varyans ve etkileşim varyanslarında da etkili olmuştur. Biyolojik verimin genotip $x$ yıl etkileşiminin varyans değeri ise 18.3 ile üçüncü sırada kendine yer bulmuştur. Biyolojik verim özelliği için Singh ve Bejiga (1990) çevreden çok yüksek oranda etkilendiğini belirtirken, Çölkesen ve ark.(2014) sadece biyolojik verim değil aynı zamanda verime etkili olan bitkide bakla ve tane sayılarının da yıllara göre değişimler gösterdiklerini belirtmişlerdir. Sözen ve Karadavut (2017) ise yılara göre mercimek bitkilerinin verim ve verime etki eden karakterlerdeki değişiminin beklenen bir değişim olduğunu belirtmişlerdir. İncelenen özelliklere ait kalıtım dereceleri değerlendirildiğinde bu değerlerin 12.1-91.0 arasında değişim gösterdiği belirlenmiştir. En düşük katlım derecesi ana dal sayısında görülürken en yüksek kalıtım derecesi değeri ise bitki boyunda ortaya konulmuştur. Ayrıca biyolojik verimin kalıtım derecesi de 81.3 ile oldukça yüksek bir değer olarak tahminlenmiştir. Bitki boyunun ana dal sayısı üzerine olumsuz yönde etki ettiği belirtilmektedir (Karadavut, 2009; Taleb ve ark., 2016; Sözen ve Karadavut, 2017). Ana dal sayısının kalıtım derecesindeki düşük değere bitki boyundaki kalıtım derecesinin yüksek değeri etkilemiş olabilir. Chauhan ve Sinha (1988) benzer etkilerin mercimek bitkilerinde görülebildiğini belirtirken, Tikka ve ark. (1997) mercimek bitkilerinde karakterler arası ilişkilerin karakter oluşumunu yüksek derecede etkilediğini belirtmişlerdir. Elde edilen bulgular bazı 
karakterlerin karşılıklı etkileşimden dolayı birbirlerini olumlu ya da olumsuz yönde etkilediklerini düşündürmektedir. Islah çalışmalarında kalıtım derecesi yüksek olan özelliklerin ön plana alınması çalışmaların başarısı açısında önemli olacaktır.

Incelenen özelliklere ait beklenen ve gözlenen genetik ilerleme değerleri Çizelge 7'de verilmiştir. Çizelge 7 incelendiğinde genetik ilerleme miktarları \%1.8 ile 12.3 arasında değişim genişliğine sahip olmuştur. En düşük genetik ilerleme miktarı \%1.8 ile bitki başına tane veriminde tespit edilirken bunu \%1.9 ile ana dal sayısı izlemiştir. Bu iki özelliğinde genetik yapı olarak çok dar bir değişim genişliğine sahip olmaları nedeniyle genetik ilerleme miktarlarının düşük olduğu ancak beklenen değerin üzerinde olması önemli bulunmuştur. Ana dal sayısında beklenen ile gözlenen arasındaki genetik ilerleme değeri farkı \%18.8 olarak belirlenirken bitki başına tane verimde ise fark \%125.0 olarak elde edilmiştir. Gözlenen genetik ilerleme değerleri içinde en yüksek değer \%12.3 ile bitkide bakla sayısında gözlenirken, bunu \%8.9 ile bitkide tane sayısı izlemiştir.

Çizelge 7. Beklenen ve gözlenen genetik ilerleme oranları

\begin{tabular}{lccc}
\hline İncelenen karakterler & Beklenen (\%) & Gözlenen (\%) & Fark (\%) \\
\hline Bitki boyu & 2.4 & 3.5 & 45.8 \\
İlk bakla yüksekliği & 2.8 & 3.3 & 17.9 \\
Ana dal sayısı & 1.6 & 1.9 & 18.8 \\
Biyolojik verim & 1.8 & 4.2 & 133.3 \\
Bitkide bakla sayısı & 4.2 & 12.3 & 192.9 \\
Bitkide tane sayısı & 3.1 & 8.9 & 187.1 \\
Bitki başına tane verimi & 0.8 & 1.8 & 125.0 \\
Yüz tane ağırlığı & 2.6 & 6.7 & 157.7 \\
Hasat indeksi & 1.4 & 2.5 & 78.6 \\
\hline
\end{tabular}

Bitkide bakla sayısının beklenen ile gözlenen değer arasındaki farklılık \%192.9 ile oldukça yüksek bir değere sahip olurken, bitkide tane sayısı da buna yakın bir değer (\%187.1) göstermiştir. Raju ve ark. (1978) kalıtım dereceleri ile genetik ilerleme arasında ilişki olduğunu belirtirken, Singh (1988) kalıtım derecesi yüksek olan karakterlerin genetik ilerlemelerinin de yüksek olduğunu belirtmiştir. Yürüttüğümüz çalışmada elde edilen bulgulara göre bitkide bakla sayısı ile bitki başına tane verimin kalıtım dereceleri ile genetik ilerlemeleri arasında ilişkinin olduğunu göstermektedir.

\section{Sonuç ve Öneriler}

Kırşehir ilinden toplanan yerel mercimek genotipleri ile yürütülen bu çalışmada mercimek genotiplerine ait verime etki eden karakterlerin çevresel etkilenme durumu, katlım dereceleri ile genetik ilerlemeleri belirlenmiştir. Elde edilen sonuçlara göre bitkide bakla sayısı ile bitkide tane sayısı özelliklerinin kalıtım dereceleri ve genetik ilerleme değerleri bakımından ön sıralarda yer aldığı görülmüştür. Belirtilen özelliklerin aynı zamanda fenotipik, genotipik ve genotip $x$ yıl etkileşim varyanslarının da değişim katkılarının da yüksek olduğu gözlenmiştir. Buna göre yerel mercimek genotiplerinin ıslah programlarında daha başarılı bir şekilde değerlendirilebilmeleri için bu özellikler üzerinde özellikle durulması faydalı olacaktır.

\section{Kaynaklar}

Akdeniz, H., Koc, A., Hosafliglu, İ., Hossain, A., Islam, M.S., Hafez, E., El Sabagh, A. 2019. Evaluation of Phenology, Growth, Yiled and Technological Characteristics of Some Winter Green Lentil (Lens culinaris Medic.) Genotypes Grown Under Mediterranean Environment. Fresenius Environmental Bulletin, 28(7): 5430-5434.

Allard, R.W. 1960. Principles of Plant Breeding. John Wiley and Sons Inc., New York.

Altınbaş, M., Sepetoğlu, H. 2002. Kışlık ekime uygun nohut geliştirmede bazı tarımsal özellikler için genotipik ve çevresel etki değerlendirmesi. Ege Üniv. Ziraat Fak. Derg., 39(3): 33-40.

Baker, R.J., Bendelow, V.M., Kaufmann, M.L. 1968. Inheritance of and interrelationships among yield and several quality traits in common wheat. Crop Sci., 8: 725-728.

Biçer, B.T. 2014. Some agronomic studies in chickpea (Cicer arietinum L.) and lentil (Lens culinaris Medic). Türk Tarım ve Doğa Bilimleri Dergisi, 1(1): 42-51.

Biçer, B.T., Sakar, D. 2008. Studies on Variability of Lentil Genotypes in Southeastern Anatolia of Turkey. Not. Bot. Hort. Agrobot., 36(1): 2024.

Boerma, H.R., Cooper, R.L. 1975. Effectiveness of early- generation yield selection of heterogeneous lines in soybeans. Crop Sci., 15: 313-315. 
Bozoğlu, H., Pekşen, E. 1997. Farklı sıra arası mesafelerinin mercimeğin tane verimi ve bazı agronomik özellikleri üzerine etkileri. Türkiye II. Tarla Bitkileri Kongresi, s. 595-597, Samsun.

Chauhan, U.S., Sinha, P.K. 1988. Correlation and path analysis in lentils. Lens Newsletter, 15(1):16-18.

Çokkızgın, A. 2007. Güney ve Güneydoğu Anadolu Bölgelerinden Toplanan Bazı Kırmızı Mercimek (Lens culinaris Medic.) Yerel Genotiplerinin Bitkisel ve Tarımsal Özelliklerinin Belirlenmesi Üzerine Bir Araştırma. Doktora Tezi, Çukurova Üniversitesi, Fen Bilimleri Enstitüsü, Adana.

Comstock, R.E., Moll, R.H. 1963. Genotypeenvironment interactions, in Statistical Genetics and Plant Breeding. National Academy of Sciences-National Research Council Publication, 982: 164-196.

Çölkesen, M., Idikut, L., Zulkadir, G., Cokkizgin, A., Girgel, U. ve Boylu, O.A. 2014. Determination of Yield and Yield Components of Various Winter Lentil Genotypes (Lens culinaris Medik.) in Kahramanmaras Conditions. Turkish Journal of Agricultural and Natural Sciences (Special Issue), 1: 1247-1253.

Düzgüneş, O., Kesici T., Kavuncu, O., Gürbüz, F. 1987. Research and Trial Methods. Journal of Agricultural Faculty of Ankara University, 381 p.

Gharti, D.B., Jha, P., Darai, R., Ghale, D., Joshi, S., Wagle, B.P. 2008. Studies on management of stemphylium blight (Stemphylium sarciniforme) of lentil (Lens culinaris L.) at NGLRP, Rampur and RARS, Nepalgunj. In: Program and Abstract of a 27th National Winter Crops Workshop "Ensuring Food Security Through Crop Diversification". Nepal Agricultural Research Council, pp. 3536.

Kan, M., Sözen, Ö., Kan, A., Karadavut, U., Yağmur, M. 2019. Orta Kızılırmak Vadisi'nde üretici şartlarında yerel kuru fasulye populasyonlarının doğal kaynak ekonomisi açısından genel değerlendirilmesi. Tarım ve Doğa Dergisi, 22(3): 389-398.

Karadavut, U. 2009. Path analysis for yield and yield components in lentil (Lens culinaris Medic.). Turkish Journal of Field Crops, 14(2): 97-104.

Karadavut, U., Palta, Ç. 2010. Chemical performance of multi-environment trials in lens (Lens Culinaris M.). Journal of the Science of Food and Agriculture, 90: 117- 120.

Kır, H., Şahan, D.B. 2019. Yield quality features of some silage sorghum and sorghumsudangrass hybrid cultivars in ecological conditions of Kırşehir Province. Turkish Journal of Agricultural and Natural Science, 6(3): 388-395.

Kökten, K., Bakoğlu, A. 2011. Elazığ Koşullarında Mürdümük (Lathyrus sativus L.)'te Farklı Sıra Arasının Tohum Verimi ve Verim Öğeleri Üzerine Etkisi. Bingöl Üniversitesi Fen Bilimleri Enstitüsü Dergisi, 1(1): 37-42.

Özpınar, H., İnal, F.N., Ay, E., Acar, A.A. ve Sabancı, C.O. 2017. Türkiye Yem Bitkileri Genetik Kaynakları. Anadolu Journal of AARI, 27(1): 51-55.

Raju, D.B., Mehra, R.B., Bahl, P.N. 1978. Genetic variability and correlations in chickpea. Trop Grain Legume Bull., 13/14: 35-39.

Rao, S.K., Yadav, S.P. 1988. Genetic analysis of biological yield, harvest index and seed yield in lentil. Lens Newslet, ICARDA, 15 (1): 3-5.

Schuler, S.F., Bacon, R.K., Finney, P.L., Gbur, E.E. 1995. Relationship of test weight and kernel properties to milling and baking quality in soft red winter wheat. Crop Sci., 35: 949-953.

Sepetoglu, H. 1992. Legumes. Ege University Faculty of Agriculture Publications, 24: 262.

Shah, B.H., Khan, J., Khetran, M.A., Kurd, A.A., Sadiq, N. 2013. Evaluation and Selection of cold and drought resistant lentil genotypes for highlands of Balochistan. Sarhad J. Agric., 29(4): 511-513.

Singh, S.P., Mehra, R.B. 1980. Adaptability studies in Bengal Gram (Cicer arietinum L.). Trop. Grain Legume Bull., 19: 51-54.

Singh, S.P. 1988. Genetic variability and path coefficient studies in chickpea. Int. Chickpea News, 18: 10-12.

Singh, K.B.ve Bejiga, B. 1990. Analysis of stability for some characters in Kabuli Chickpea. Euphytica, 49: 223-227.

Sözen, Ö., Karadavut, U. 2017. Bazı Yeşil mercimek genotiplerinde dane verimi ve verim komponentleri arasındaki ilişkilerin belirlenmesi. Tarla Bitkileri Merkez Araştırma Enstitüsü Dergisi, 26(1): 104-110.

Sözen, O., Karadavut, U. 2017. Determination of the relationship between yield and yield components of winter red lentil genotypes under the conditions of Amik plain. Turkish Journal of Agricultural and Natural Sciences, 4(4): 468-476.

Sözen, Ö., Yağmur, M., Karadavut, U., Sağlam, H.D., Bardak, A., Kan, M., Kan, A. 2019. Orta Kızılırmak Vedisi'nden toplanan beyaz taneli yerel kuru fasulye genotiplerinin morfolojik varyabilitesinin belirlenmesi üzerine bir araştırma. Türk Tarım ve Doğa Bilimleri Dergisi, 6(2): 314-323. 
Subhani, G.M., Muhammad, N., Malhi, A.R. 2007. Status and scope of lentil production in Punjab, Pakistan. Proc. Int, Conf. on "achieving sustainable pulses production in Pakistan, Agric. Foundation of Pakistan, pp. 73-75.

Taleb, M.H., Khodambashi, M., Shiran, B. 2016. Evaluation of seed characteristics in three lentil (Lens culinaris Medik) genotypes. Scientia Agriculturae, 13 (2): 80-84.

Tikka, S.B.S., Asama, B.N., Gupta, V.K. 1997. Interrelationships of Quantitative characters with seed yield in lentil (Lens culinaris Medic). Ind. J. Heredity, 9(1): 1-6.

Tripathi, A.K. 1998. Variability analysis in chickpea. Adv. Plant Sci., (2): 291-292. 